\title{
Climate Change: A Bibliometric Review
}

\author{
Ebru Bakaç ${ }^{1 *}$ \\ 1* Sinop University, Faculty of Education, Departmant of Education, Sinop, Turkey, (ORCID: 0000- 0003-4263-8785), ebrubakac@sinop.edu.tr
}

(First received 31 July 2021 and in final form 11 October 2021)

(DOI: 10.31590/ejosat.976907)

ATIF/REFERENCE: Bakac, E. (2021). Climate Change: A Bibliometric Review. European Journal of Science and Technology, (27), 776-783.

\begin{abstract}
The aim of this research is to bibliometrically examine the articles published between 2017-2021 on the subject of climate change. Research data were obtained using the Scopus database. As the article selection criteria, the articles written in the last five years and containing the concept of climate change in the title and abstract were filtered out. In addition, the criteria for the articles to be in English and to have the full text published were also taken into account. According to these criteria $(\mathrm{n}=662)$ articles were obtained. The articles were analyzed using the VOSviewer program. As a result of the analyzes, when the distribution of the articles on climate change by subject areas is examined, it has been determined that the most publications are produced in the fields of social sciences, environmental sciences and earth and planetary sciences, and the number of articles is increasing every year. In addition, it has been seen that the subject is discussed in fields such as agriculture and biological sciences, molecular biology and genetics, engineering, economics and medicine. In addition, it was found that the countries with the highest number of studies on climate change were United Kingdom, United States, Germany, Netherlands and Australia, respectively. Collaborations between the authors have been revealed. According to the situation emerging in the abstracts, the most common words in the articles are government, model, health, scenario and temperature. The most striking keywords on the subject are adaptation around the concept of climate change, global warming, environment, water management and energy consumption.
\end{abstract}

Keywords: Climate change, Bibliometric analysis, VOSviewer program, Energy consumption, Water management.

\section{İklim Değişikliği: Bibliyometrik Bir İnceleme}

\section{Öz}

Bu araştırmanın amacı iklim değişikliği konusu ile ilgili olarak 2017-2021 yılları arasında yapılan makalelerin bibliyometrik olarak incelenmesidir. Araştırma verileri Scopus veri tabanı kullanılarak elde edilmiştir. Makale seçim kriteri olarak son beş yıl içerisinde yazılmış, başlık ve özetinde iklim değişikliği kavramı bulunan makaleler filtrelenmiştir. Ayrıca makalelerin İngilizce dilinde olması ve tam metninin yayınlanmış olması kriterleri de dikkate alınmıştır. Bu kriterlere göre (n=662) makale elde edilmiştir. Makaleler VOSviewer programı kullanılarak analiz edilmiştir. Analizler sonucunda iklim değişikliği ile ilgili incelenen makalelerin konu alanlarına göre dağılımı incelendiğinde en fazla sosyal bilimler, çevre bilimleri ve dünya ve gezegen bilimleri alanlarında yayın üretildiği ve her yıl makale sayısının giderek arttı̆̆ı saptanmıştır. Ayrıca tarım ve biyolojik bilimler, moleküler biyoloji ve genetik, mühendislik, ekonomi ve tıp gibi alanlarda da konunun ele alındığı görülmüştür. Ayrıca iklim değişikliği konusunda en fazla çalışma yapılan ülkelerin sırası ile Birleşik Krallık, Amerika Birleşik Devletleri, Almanya, Hollanda ve Avustralya olduğu bulunmuştur. Yazarlar arasındaki işbirliği ortaya konmuştur. Özetlerde ortaya çıkan duruma göre makalelerde en fazla yer alan kelimeler hükümet, model, sağlık, senaryo ve sıcaklıktır. Konu ile ilgili en dikkat çeken anahtar kelimeler iklim değişikliği kavramı etrafında oluşan adaptasyon, küresel ısınma, çevre, su yönetimi ve enerji tüketimidir.

Anahtar Kelimeler: Iklim değişikliği, Bibliyometrik analiz, Vosviewer programı, Enerji tüketimi, Su yönetimi.

\footnotetext{
*Corresponding Author: ebrubakac@sinop.edu.tr
} 


\section{Introduction}

Human-induced climate change has been affecting our planet as a remarkable problem in recent years (Hardy, 2003). Global climate change significantly changes the structure of some ecosystems and causes the extinction of some species (Stenseth et al., 2005). Climates are formed as a result of the natural effect of greenhouse gases. This effect occurs through the effect of gases such as water vapor, carbon dioxide, ozone, methane and nitrite oxide, which absorb heat from the earth and the lower layer of the atmosphere and transmit it back to the earth more (Karl et al., 2009). Changing temperatures, precipitation patterns and increasing atmospheric $\mathrm{CO}_{2}$ concentrations cause significant changes in natural and modified forests; this situation causes some irreversible damages on human health (Kirilenko \& Sedjo, 2007). Energy consumption also has a significant impact on climate change. Aerosols, which are formed as a result of burning coal, petroleum and organic materials, reflect the sun rays reaching the atmosphere back to space, unlike the gases that create the greenhouse effect; however, they cause other difficult problems such as acid rain and deterioration in air quality (UNEP, 2001). Especially the melting of the glaciers on the land and the rise in the water level in the seas will cause some countries to be under water. The rise in sea waters means that it puts great pressure on clean water resources on land. The most important danger is the mixing of sea water with fresh water resources. On the other hand, increasing salt water pressure will cause the loss of highly productive areas in coastal areas (Neubert, 2001).

In the literature, it was seen that there are bibliometric analysis studies examining different variables for climate change. Rana (2020) were examined climate change and disaster awareness, Wang, Zhao, \& Wang (2018) were stated that climate change adaptation, Sweileh (2020) were examined climate change and food security, Huang, Chen \& Zhou (2020) were examined climate change and carbon emissions, Omoregbe et al . (2020) the were examined effect of climate change on reducing carbon emissions, Belter \& Seidel (2013) were examined climate change research in engineering. Zhang, Wang, Liang \& Chen (2016) bibliometrically analyzed the studies examining the effect of carbon tax on climate change. Wang, Pan, Ke, Wang \& Wei (2014) evaluated 3004 articles published between 1991 and 2012 in their research; It was determined that the relationship between climate change and issues such as health problems, food safety and water management is examined. Çomakl (2021) conducted a bibliometric analysis of the articles on the retention of soil organic carbon, which has an important role in the improvement of the negative effects of climate change, in terrestrial ecosystems. Seyhan (2021) also analyzed the published works on green innovation and managerial practices in the study of global warming, Covid-19, increasing pollution, decreasing fossil resources, etc. He/She states that the subject will be examined more in the coming period due to the fact that the factors come to the fore. Soylu \& Özkaya (2021) stated that researchers showed little interest in publications on climate change and food safety in their study that produced a bibliometric profile of articles published in peer-reviewed journals on climate change and food safety. Finally, Ünlü, Sever \& Akpınar (2011) examined the results of articles and papers on global warming and greenhouse effect published in the field of environmental education in Turkey, in which teachers and students have many misconceptions about global warming and greenhouse effect, their academic knowledge level is insufficient and they are not scientific. They concluded that it was far. For this reason, it has become important to raise awareness about climate change.

The concept of climate change emerges as a concept that is studied with great importance in today's scientific world. It is seen that almost every branch of science, from science to social sciences, deals with the subject with its own perspective. For this reason, there has been a rapid increase in the number of researches on the subject in recent years. In this context, it is aimed to bring a different dimension to the subject by evaluating the areas where climate change is most studied and the findings obtained as a result of the researches. For this reason, the aim of this research is to bibliometrically examine the articles made between 2017-2021 on the subject of climate change. For this purpose, answers to the following questions were sought:

What is the distribution of articles on climate change by years? Who are the authors with the most articles on climate change? What is the distribution of articles on climate change by subject areas?

What is the distribution of articles on climate change according to the journals in which they are published?

What is the distribution of articles on climate change by universities?

What is the distribution of articles on climate change by country? What is the cluster density view of the article abstracts? What is the view of collaboration between article authors?

\section{Material and Method}

\subsection{Model of the Research}

In this research, bibliometric analysis method based on scientific mapping technique based on quantitative research design was used to analyze the articles dealing with the issue of climate change. Bibliometric analysis includes statistical methods to identify qualitative and quantitative changes in a particular scientific research topic, to profile publications on the subject, and to detect trends within a discipline (Rey-Martí et al., 2016). In the bibliometric analysis method, a wide variety of analysis techniques are used, including citation-based and performancebased analysis, by classifying publications according to countries, universities, research groups or authors (Gaviria-Marin et al., 2019). Within the scope of this research, $(n=662)$ articles were obtained and analyzed using sub-titles such as title, abstract, keywords and collaboration between authors.

\subsection{Article Selection Criteria}

Since the issue of climate change is an interdisciplinary subject, it is seen that there are many studies in the literature. Therefore, some criteria were taken into consideration in the selection of the article. Scopus database was used for article selection. In the Scopus database, $n=219.153$ articles written on the subject of climate change were found. (TITLE (climate AND change) AND ABS ( articles ) ) AND PUBYEAR > 2016 AND PUBYEAR < 2022 AND ( LIMITTO ( PUBSTAGE , "final" ) ) AND ( LIMIT TO ( OA, "all" ) AND ( LIMIT-TO ( DOCTYPE, "ar" ) ) AND ( LIMIT TO ( LANGUAGE , "English" ) ) AND ( LIMIT-TO ( SRCTYPE , "j" ) ) Articles with the concept of climate change in the title and abstract in the last five years were filtered out. In addition, the criteria for the articles to be in English 
and to have the full text published were also taken into account. According to these criteria, $n=662$ articles were obtained in the database.

\subsection{Analysis of Data}

Different scientific techniques and computer programs are used to create bibliometric maps. In the study, the VOSviewer program was preferred for the visualization of the data set, as it offers the most advanced and valid techniques for each step in the science mapping process. This program is used for the creation and visualization of bibliometric networks based on citation, bibliographic matching, co-authorship or citation relationships (VOSviewer, 2021).

\section{Results and Discussion}

Table 1.Yearly distribution of the articles

\begin{tabular}{lc}
\hline Year & N \\
\hline 2021 & 97 \\
2020 & 150 \\
2019 & 141 \\
2018 & 143 \\
2017 & 131 \\
\hline
\end{tabular}

When the articles written on climate change in the last five years were examined (Table 1), it was seen that the most articles on the subject were produced in $2020(n=150)$. In addition, it is noteworthy that an increasing number of studies have been brought to the literature over the years in the number of articles. Since 2021 has not yet been completed, it does not seem very possible to comment on this year's studies.

Table 2. Distribution of authors' who have the highest number of articles

\begin{tabular}{ll}
\hline The name of the writer & N \\
\hline Harper, S.L. & 5 \\
Coggins, S. & 3 \\
Ford, J.D. & 3 \\
Jerneck, A. & 3 \\
Kverndokk, K. & 3 \\
\hline
\end{tabular}

According to Table 2, the author with the highest number of articles on climate change is S.L. Harper $(n=5)$. It was seen that other authors have an equal number of articles $(n=3)$. These authors are S. Coggins, J.D. Ford, A. Jerneck and K. Kverndokk.

\subsection{Limitations}

The findings obtained in the research are completely based on computer-based data. Articles published on climate change over a five-year period and covering different disciplines were used as data sources. Only journals in the Scopus database were included in the research data. The data obtained from conference papers, letters, compilations, and book chapters in this database are excluded.

Table 3. Distribution of articles by subject areas

\begin{tabular}{lr}
\hline Subject Area & N \\
\hline Social Sciences & 379 \\
Environmental Science & 297 \\
Earth and Planetary Sciences & 110 \\
Agricultural and Biological Sciences & 79 \\
Energy & 78 \\
Arts and Humanities & 59 \\
Engineering & 40 \\
Economics, Econometrics and Finance & 39 \\
Medicine & 33 \\
Biochemistry, Genetics and Molecular Biology & 28 \\
\hline
\end{tabular}

When the distribution of articles by subject areas was analyzed, Social Sciences $(n=379)$, Environmental Sciences $(n=297)$ and Earth and Planetary Sciences $(n=110)$ are in the first three ranks. In addition, it was seen that the subject is discussed in fields such as Agriculture and Biological Sciences, Molecular Biology and Genetics, Engineering, Economics and Medicine (Table 3).

Table 4. Distribution of the articles according to the journals

\begin{tabular}{lc}
\hline Title of Article & $\mathbf{N}$ \\
\hline Sustainability & 40 \\
Climatic Change & 23 \\
Climate Policy & 15 \\
JJODRS & 11 \\
Functional Ecology & 10 \\
PacificJournalism Review & 10 \\
Water Switzerland & 9 \\
PTOT Royal Society B Biological Sciences & 8 \\
WIRCC & 8 \\
Energies & 7 \\
\hline
\end{tabular}

When Table 4 was examined, the journals of Sustainability $(n=40)$, Climatic Change $(n=23)$ and Climate Policy $(n=15)$ are in the top three ranks in the journals with the highest number of articles. 
European Journal of Science and Technology

Table 5. Distribution of the articles by universities

\begin{tabular}{lc}
\hline Affiliation & N \\
\hline Wageningen University & 16 \\
University of Leeds & 14 \\
Lunds Universitet & 14 \\
Helsingin Yliopisto & 12 \\
Universität Hamburg & 12 \\
\hline
\end{tabular}

When the universities with the highest number of articles on climate change were examined, Wageningen University $(n=16)$, University of Leeds $(n=14)$, Lunds Universitet $(n=14)$, Helsingin Yliopisto $(n=12)$ and Universität Hamburg $(n=12)$ is coming the first. It was seen that these universities are generally located in Europe (Table 5).
Table 6. Distribution of countries where the articles are produced the most

\begin{tabular}{lc}
\hline Countries & N \\
\hline United Kingdom & 157 \\
United States & 124 \\
Germany & 80 \\
Netherlands & 49 \\
Australia & 46 \\
\hline
\end{tabular}

When Table 6 was examined, the countries with the highest number of studies on climate change are listed in order. United Kingdom $(n=157)$, United States $(n=124)$, Germany $(n=80)$, Netherlands $(n=49)$ and Australia $(n=46)$. This situation can be interpreted as that researchers living in developed countries generally pay special attention to climate change

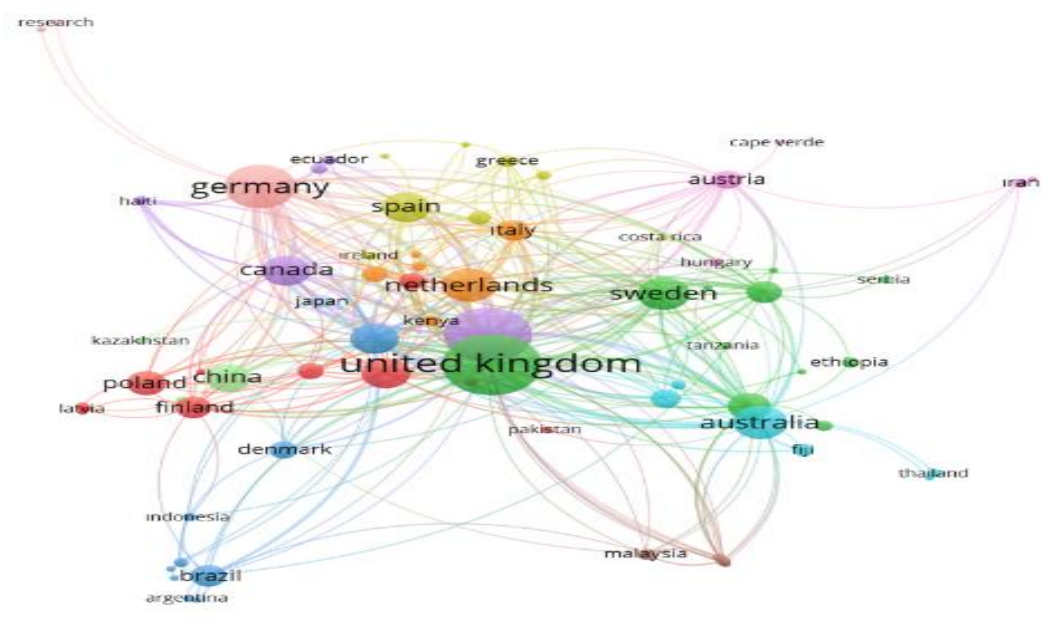

Figure 1. Network view showing cooperation between countries $(n=75)$
According to Figure 1, when the countries where the published articles on climate change are examined, it was understood that the countries are gathered under 13 clusters according to the network view $(\mathrm{n}=75)$. 
Sor vosviewer

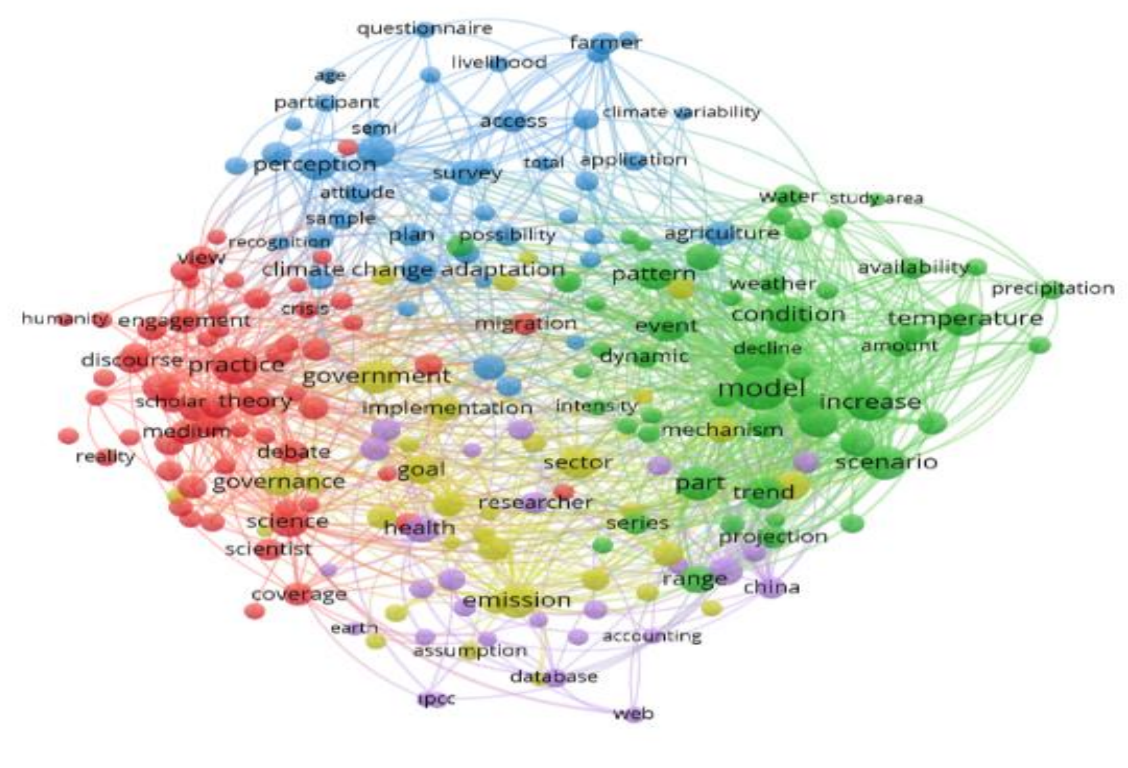

Figure 2. Cluster density view according to article abstracts $(n=216)$

When the cluster density view of the article summaries on climate change is examined, it is seen that the studies are grouped under five clusters (figure 2). According to the appearance in the abstracts, the most common words in the articles are the words such as government, model, health, scenario and temperature.

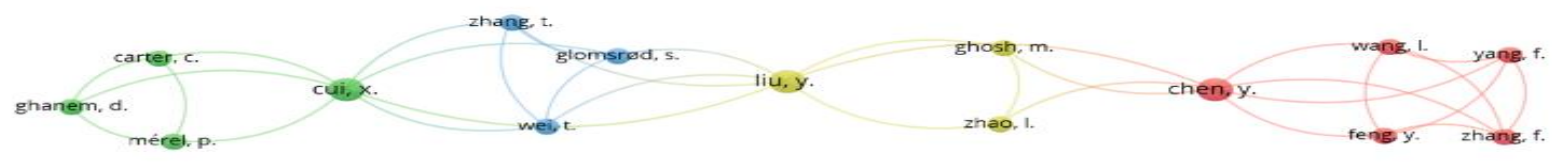

fos vosviewer

Figure 3. Network view which collaboration between authors

When Figure 3 was examined, the existing collaborations between the authors researching the issue of climate change can be seen. Accordingly, when at least one author criterion was selected among the authors, it was seen that there are four different clusters. It was understood that authors X. Culi, Y. Liu Y. Chen co-authored to form two clusters 


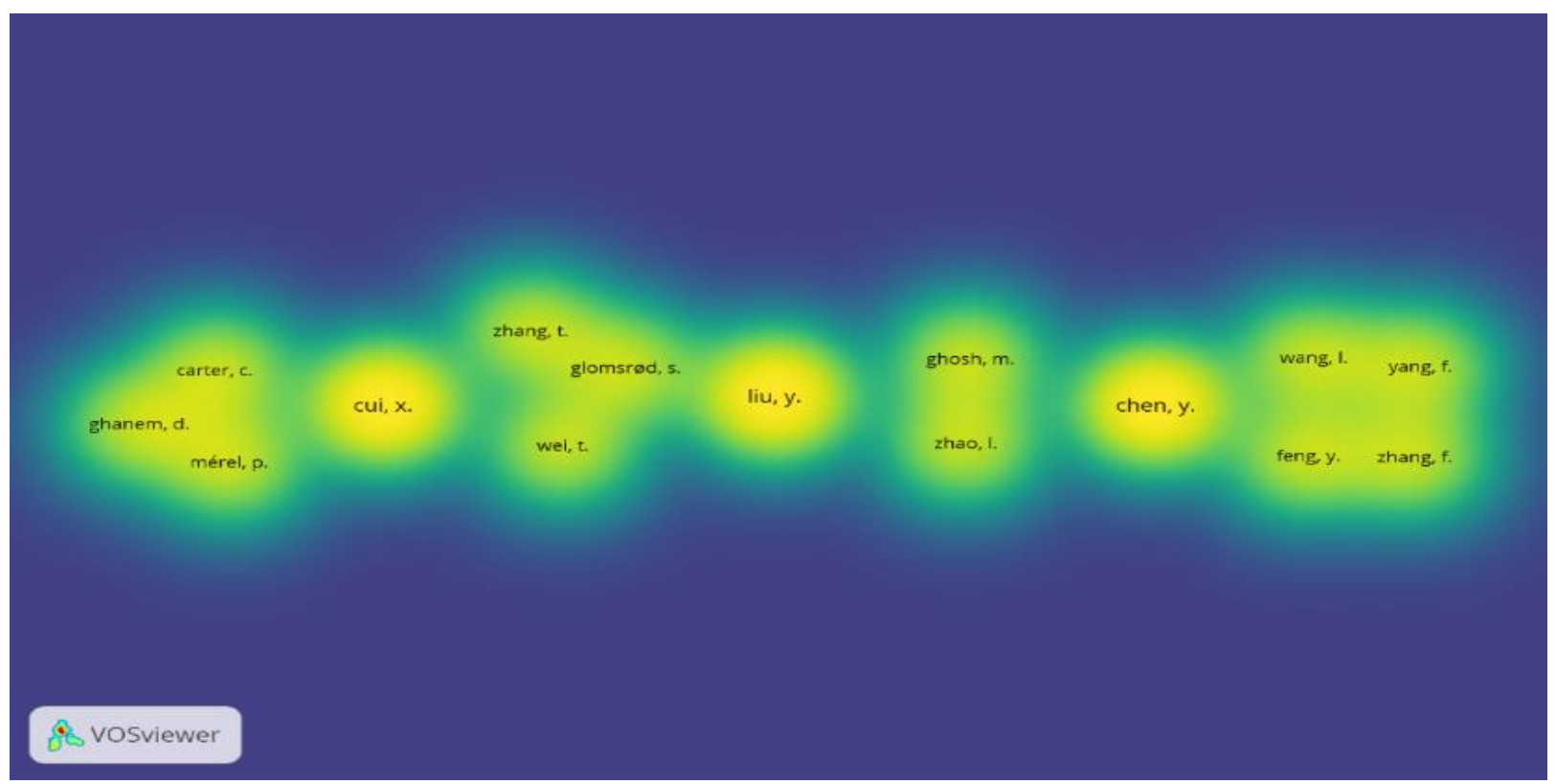

Figure 4. Density view which collaboration between authors

When Figure 4 was examined, the density view which the cooperation between the authors was seen and it was understood that the authors are grouped to form four clusters.

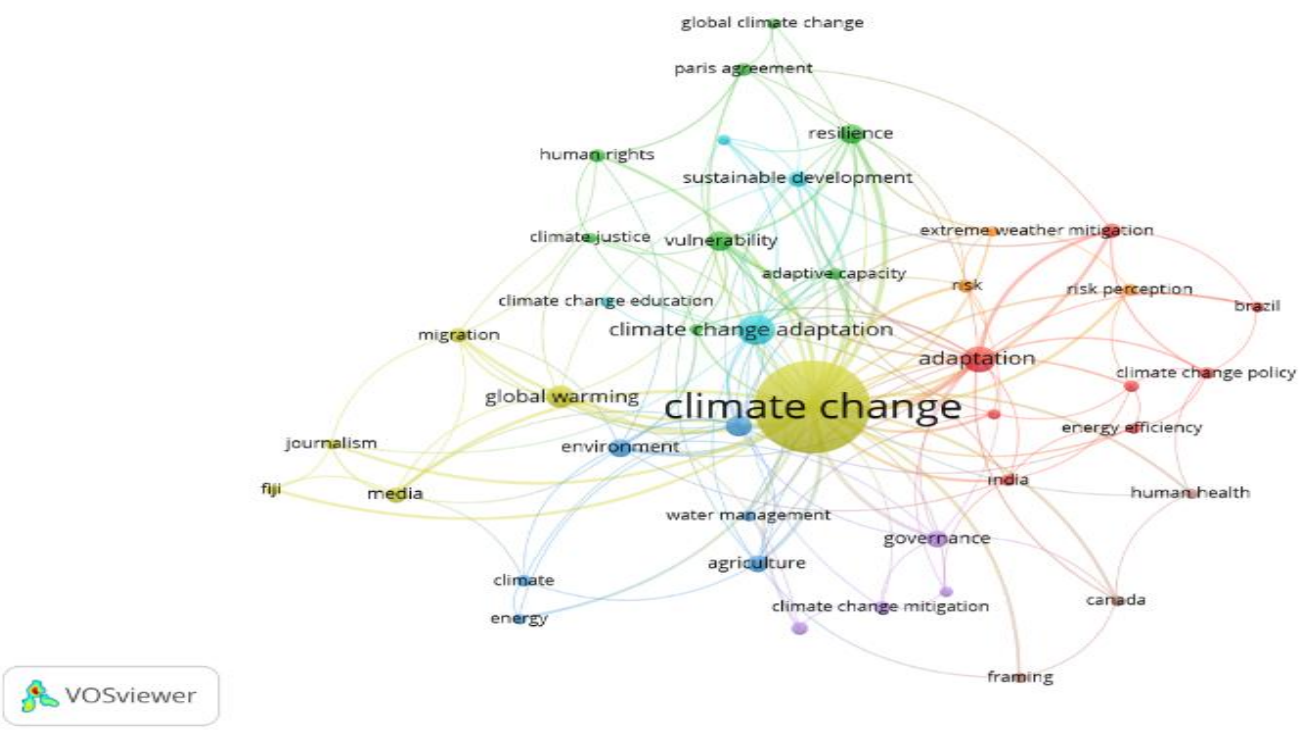

Figure 5. Network view of keywords $(N=42)$

According to the common keywords created by the authors, it was determined that $(n=42)$ words and eight clusters were formed for the articles on climate change. The most striking concepts related to the subject are adaptation around the concept of climate change, global warming, environment, water management and energy consumption (Figure 5).

The aim of this research is to bibliometrically examine the articles published between 2017-2021 on the subject of climate change. As a result of the research, it was determined that the articles examined on climate change were mostly produced in areas such as social sciences, environmental sciences and Earth and Planetary Sciences, and an increasing number of articles were written every year. In addition, it has been seen that the subject is discussed in fields such as agriculture and biological sciences, molecular biology and genetics, Engineering, Economics and
Medicine. In addition, it was found that the countries with the highest number of studies on climate change were United Kingdom, United States, Germany, Netherlands and Australia, respectively. Sustainability, Climatic Change and Climate Policy journals are in the first three places in the list of journals with the most articles. As a result of the study, the collaborations between the authors were also revealed. According to the situation emerging in the abstracts, the most common words in the articles are government, model, health, scenario and temperature. The most striking keywords on the subject are adaptation around the concept of climate change, global warming, environment, water management and energy consumption.

From the articles examined, it was seen that an increasing number of articles are produced every year in fields such as social sciences and environmental sciences in general, according to the relevant subject areas of the concept of climate change. Similar to this finding, Haunschild, Bornmann \& Marx (2016) found that the 
total number of articles increased rapidly by doubling every five to six years. Sweileh (2020) also states that the subject has become important in the last ten years. Polat, Duzgun \& Yesiltas (2019) state that the theses on climate change, which support the research findings, are generally carried out in fields such as geography, humanities, and marine sciences.

The journals with the highest number of articles are Sustainability, Climatic Change and Climate Policy journals. Similarly, Geng, Tian, Zhong, Wu, Yu, and Xiao (2018) found that Journal of Cleaner Production and Sustainability and Energy Policy journals were the journals that accepted the most publications on climate change. Wang, Zhao \& Wang (2018) also states that the journal with the highest number of publications is Climatic Change, as in this study.

It was understood that the countries with the highest number of studies on climate change are United Kingdom, United States, Germany, Netherlands and Australia, respectively. Haunschild, Bornmann \& Marx (2016) also found that the United States of America is the country with the highest number of articles on climate change, followed by England, Germany and Canada. Sweileh (2020) also found that France and the Netherlands are also the countries with the highest percentage of documents with international authors. It is understood that there are many studies

\section{Conclusions and Recommendations}

Climate change continues to be one of the important problems of today's world. For this reason, it is seen that the subject, which finds a research area in different disciplines, is evaluated from a very broad perspective. Climate change, which has found a research area in fields such as agriculture, economy, engineering and genetics, especially in environmental sciences and social sciences, has become an area where more and more researches are carried out with the aim of creating a more livable world. In this case, researchers may be advised to focus on practical rather than theoretical research to solve the problem. On the other hand, if the climate change problem is considered to be a global problem, research funds that allow researchers from different countries to cooperate can be supported by governments in order to increase cooperation between countries. Attempts can be made to increase cooperation between researchers working in areas closely related to the subject, such as water management, agriculture, energy consumption, and researchers working in the field of climate change. Finally, considering that there is a huge increase in the number of articles on the subject, it can be said that there should be an increase in the number of master's and doctoral theses prepared in universities in order to deal with the subject scientifically.

\section{References}

Belter, C. W., \& Seidel, D. J. (2013). A bibliometric analysis of climate engineering research. Wiley Interdisciplinary Reviews: Climate Change, 4(5), 417-427.

Çomaklı, E. (2021). Toprak organik karbonu ve toprak organik karbon stokları üzerine 1970-2021 y1lları arasında yapılan araştırmaların bibliyometrik analizi. Avrupa Bilim ve Teknoloji Dergisi, (25), 517-524

Gaviria-Marin, M., Merigó, J. M., \& Baier-Fuentes, H. (2019). Knowledge management: A global examination based on on the subject in European countries (Shen, Wei \& Sheng, 2021; Polat, Duzgun \& Yesiltas, 2019). The reason for this situation can be explained as the fact that these countries are more sensitive to climate change due to their industrial development. Soylu \& Özkaya (2021) also recommends that more publications be made in terms of climate change and food safety in our country in order to comply with international norms and to protect and maintain public health.

The most striking keywords about climate change are adaptation around the concept of climate change, global warming, environment, water management and energy consumption. Similarly, it has been determined that the most used keywords by Sweileh (2020) are climate change, food security, drought, adaptation, agriculture and water scarcity. Haunschild, Bornmann \& Marx (2016) also concluded that the word climate is the most used word as a result of the title analysis, and that the word impact has started to be used at very high rates over time. Again, $\mathrm{Wu}$, Geng, Tian, Zhong, Wu, Yu \& Xiao (2018) stated that greenhouse gas emissions, energy, water, health and transportation are the most used keywords. Wang, Zhao and Wang (2018) determined that climate change, adaptation, vulnerability, ecosystem, socioeconomic system, agriculture, region, extreme situations, mitigation and sustainability are the most used keywords.

bibliometric analysis. Technological Forecasting and Social Change, 140, 194-220.

Hardy, J. T. (2003). Climate change: causes, effects, and solutions. John Wiley \& Sons.

Haunschild, R., Bornmann, L., \& Marx, W. (2016). Climate change research in view of bibliometrics. Plos One, 11(7), $1-19$.

Huang, L., Chen, K., \& Zhou, M. (2020). Climate change and carbon sink: a bibliometric analysis. Environmental Science and Pollution Research, 27(8), 8740-8758.

IEA(International Energy Agency) (2008). World Energy Outlook 2008. OECD. Paris.

Karl, T. R., Melillo, J. M., Peterson, T. C., \& Hassol, S. J. (Eds.). (2009). Global climate change impacts in the United States. Cambridge University Press.

Kirilenko, A. P., \& Sedjo, R. A. (2007). Climate change impacts on forestry. Proceedings of the National Academy of Sciences, 104(50), 19697-19702.

Neubert, S. (2001). Wasser und Ernährungssihereit. Aus Politik und Zeitgeschichte, 48-49, 13-22.

Omoregbe, O., Mustapha, A. N., Steinberger-Wilckens, R., ElKharouf, A., \& Onyeaka, H. (2020). Carbon capture technologies for climate change mitigation: A bibliometric analysis of the scientific discourse during 19982018. Energy Reports, 6, 1200-1212.

Polat, E., Düzgün, E., \& Yeşiltaş, M. (2019). İklim değişikliğinin turizme etkisini belirlemeye yönelik hazırlanan lisansüstü tezlerin bibliyometrik profili. Gümüşhane Üniversitesi Sosyal Bilimler Enstitüsü Elektronik Dergisi, 10, 240-249.

Rana, I. A. (2020). Disaster and climate change resilience: A bibliometric analysis. International Journal of Disaster Risk Reduction, 101839.

Rey-Martí, A., Ribeiro-Soriano, D., \& Palacios-Marqués, D. (2016). A bibliometric analysis of social entrepreneurship. Journal of Business Research, 69(5), 1651-1655.

Seyhan, M. (2021). Yönetsel Bağlamda Yeşil İnovasyonun Evriminin Bibliyometrik Analizi. Gaziantep University Journal of Social Sciences, 20(2). 
Shen, C., Wei, M., \& Sheng, Y. (2021). A bibliometric analysis of food safety governance research from 1999 to 2019. Food Science Nutrition, 1-19.

Soylu, A. G., \& Özkaya, F. D. (2021). İklim Değişikliği ve Gıda Güvenliği Konulu Hakem Denetimli Makalelerin Bibliyometrik Profili. Türk Turizm Araştırmaları Dergisi, 5(2), 1589-1602.

Stenseth, N., Ottersen,G., Hurrell,J. W., \& Belgrano, A. (2005). Marine ecosystems and climate variation. Oxford: Oxford University Press.

Sweileh, W. M. (2020). Bibliometric analysis of peer-reviewed literature on food security in the context of climate change from 1980 to 2019. Agriculture and Food Security, 9(11), 115.

UNEP (2001). Climate change information kit. http://unfccc.int/resource/ iuckit/cckit2001en.pdf.

Ünlü, İ., Sever, R., \& Akpınar, E. (2011). Türkiye'de çevre eğitimi alanında yapılmış küresel ısınma ve sera etkisi konulu akademik araştırmaların sonuçlarının incelenmesi. Erzincan Ĕ̆itim Fakültesi Dergisi, 13(1), 39-54.

VOSviewer. (2021). Welcome to VOSviewer. Centre for science and technology studies, leiden university. https://www.vosviewer.com/, Erişim Tarihi: 28.07.2021.

Wang, B., Pan, S. Y., Ke, R. Y., Wang, K., \& Wei, Y. M. (2014). An overview of climate change vulnerability: a bibliometric analysis based on Web of Science database. Natural hazards, 74(3), 1649-1666.

Wang, Z., Zhao, Y., \& Wang, B. (2018). A bibliometric analysis of climate change adaptation based on massive research literature data. Journal of Cleaner Production,199, 10721082.

Zhang, K., Wang, Q., Liang, Q. M., \& Chen, H. (2016). A bibliometric analysis of research on carbon tax from 1989 to 2014. Renewable and sustainable energy reviews, 58, 297310. 